\title{
Broad-Scale Relationships between Shorebirds and Landscapes in the Southern Great Plains
}

Author(s): Gene Albanese and Craig A. Davis

Source: The Auk, 130(1):88-97. 2013.

Published By: The American Ornithologists' Union

URL: http://www.bioone.org/doi/full/10.1525/auk.2012.11240

BioOne (www.bioone.org) is a nonprofit, online aggregation of core research in the biological, ecological, and environmental sciences. BioOne provides a sustainable online platform for over 170 journals and books published by nonprofit societies, associations, museums, institutions, and presses.

Your use of this PDF, the BioOne Web site, and all posted and associated content indicates your acceptance of BioOne's Terms of Use, available at www.bioone.org/page/terms_of_use.

Usage of BioOne content is strictly limited to personal, educational, and non-commercial use. Commercial inquiries or rights and permissions requests should be directed to the individual publisher as copyright holder. 


\title{
BROAD-SCALE RELATIONSHIPS BETWEEN SHOREBIRDS AND LANDSCAPES IN THE SOUTHERN GREAT PLAINS
}

\author{
Gene Albanese ${ }^{1}$ and Craig A. Davis \\ Department of Natural Resource Ecology and Management, Oklahoma State University, Stillwater, Oklahoma, USA
}

\begin{abstract}
Stopover use by migrating shorebirds is affected by patch-level characteristics of habitat, but the relative influence of broadscale factors is poorly understood. We conducted surveys of ten 10-km-radius landscapes in north-central Oklahoma from 2007 through 2009 to examine the influence of the amount and composition of wetland habitats and surrounding land cover on shorebird use during migration. We used generalized linear modeling and an information-theoretic framework to identify factors that best explained species richness, total abundance, and abundance of four groups of shorebirds classified by breeding status and migration distance. Total abundance and richness both increased with the area of wetland habitat within a landscape, regardless of the composition of semi-natural and developed land cover surrounding wetlands. Abundance of shorebird species with different migration strategies varied in relation to the composition of wetland types within a landscape. The amounts of various permanent and semi-permanent wetlands best explained abundance of resident species. Short-distance migrant abundance was best explained by the amount of permanent lacustrine wetlands. The amounts of temporary and semipermanent floodwater habitats were important predictors for abundance of intermediate- and long-distance migrants, although permanent riverine habitats were also important for intermediate-distance migrants. Shorebird species richness was best explained by the amounts of floodwater habitats and permanent riverine wetlands. Broad-scale studies thus provide important insights on use of stopover habitats by migratory shorebirds. Within this region, conservation of riverine habitats with a large complement of ephemeral habitats is necessary to provide the stopover habitat for migrating shorebirds. Received 20 October 2011, accepted 31 August 2012.
\end{abstract}

Key words: avian migration, habitat use, landscape composition, landscape ecology, prairie wetlands, stopover, wetland cluster.

\section{Relaciones a Gran Escala entre las Aves Playeras y el Paisaje en las Grandes Planicies del Sur}

RESUMEN.-El uso de los sitios de parada por parte de las aves playeras migratorias es afectado por características del hábitat a pequeña escala, pero la influencia relativa de los factores de gran escala es pobremente conocida. Hicimos censos en paisajes de $10 \mathrm{~km}$ de radio en la zona norcentral de Oklahoma entre 2007 y 2009 para examinar la influencia de la cantidad y composición de los humedales y de los hábitats a sus alrededores en su uso por parte de las aves playeras durante la migración. Usamos modelos lineales generalizados y un marco de teoría de información para identificar los factores que mejor explican la riqueza de especies, la abundancia total y la abundancia de cuatro grupos de aves playeras clasificados según su estado reproductivo y distancia migratoria. La abundancia total y la riqueza se incrementaron con el área de humedales dentro de un paisaje, independientemente de la composición semi-natural o desarrollada de los hábitats a su alrededor. La abundancia de las especies de aves playeras con diferentes estrategias migratorias varió en relación con la composición de los humedales en un paisaje. Las cantidades de humedales permanentes y semipermanentes fueron los mejores predictores de la abundancia de especies residentes. La abundancia de los migrantes de cortas distancias fue mejor explicada por la cantidad de humedales lacustres permanentes. Las cantidades de hábitats inundables temporales y semipermanentes fueron importantes predictores de la abundancia de migrantes de distancias largas e intermedias, aunque los hábitats ribereños permanentes también fueron importantes para los migrantes de distancias intermedias. La riqueza de especies de aves playeras fue mejor explicada por las cantidades de hábitats inundables y de humedales ribereños permanentes. Esto demuestra que los estudios a gran escala proveen pautas importantes sobre el uso de hábitats de parada por parte de las aves playeras migratorias. La conservación de los hábitats ribereños junto con la de hábitats efímeros en esta región es necesaria para proveer hábitat de parada para las aves playeras migratorias.

NeARly Half of the shorebird species in North America are in decline (Brown et al. 2001, Morrison et al. 2001), and worldwide, nearly $50 \%$ of the shorebird populations with known trends may likewise be declining (Wetlands International 2002, Stroud 2003). Concerns over these apparent declines have led researchers to identify possible causes on breeding and wintering grounds (Jehl

${ }^{1}$ Present address: Kansas Cooperative Fish and Wildlife Research Unit, 211 Leasure Hall, Kansas State University, Manhattan, Kansas 66502, USA. E-mail: albanese@ksu.edu

The Auk, Vol. 130, Number 1, pages 88-97. ISSN 0004-8038, electronic ISSN 1938-4254. @ 2013 by The American Ornithologists' Union. All rights reserved. Please direct all requests for permission to photocopy or reproduce article content through the University of California Press's Rights and Permissions website, http://www.ucpressjournals. com/reprintInfo.asp. DOI: 10.1525/auk.2012.11240 
and Lin 2001, Morrison et al. 2004), but recent studies have suggested that population limitation may also occur during migration (Baker et al. 2004, Morrison 2006). Shorebirds that migrate through the interior of North America may be more vulnerable to decline than oceanic or coastal migrants because of intrinsic factors associated with a transcontinental migration strategy (Thomas et al. 2006). Moreover, many interior migrants depend on a wide variety of wetlands that have experienced extensive losses (Dahl and Allord 1996). These wetlands are predominantly outside of established preserve networks (Skagen et al. 2008), and forecasts of pervasive land transformation through agricultural intensification and climate change (Tilman et al. 2001, Intergovernmental Panel on Climate Change 2007) emphasize recent conservation concerns directed at shorebirds that migrate through the interior of North America (Skagen 2006).

Differences among wetland habitat conditions (e.g., vegetation height, amount of available mudflat and vegetation cover, and water depth) influence the richness and abundance of migrating shorebirds among wetland stopover sites (Skagen and Knopf 1994a, Webb et al. 2010). Other factors, such as migration strategy, may also influence patterns of habitat use, but these patterns vary among and within shorebird species, depending on the predictability and availability of wetland habitats and the resources they provide (e.g., invertebrate foods; Piersma 2007, Warnock 2010). Although the suitability of a wetland for migrating shorebirds depends on the habitat conditions within the wetland, the density of wetlands within the surrounding landscape may better explain the distribution patterns of migratory shorebirds in the interior of North America (Webb et al. 2010, Albanese 2011). The vagaries of annual and seasonal weather patterns cause wide spatiotemporal variation in the distribution of wetlands within this region (Skagen et al. 2008, Albanese et al. 2012). Extended dry conditions may eliminate ephemeral wetlands but expose habitats along the edges of more permanent wetlands. Wet weather patterns provide water to ephemeral wetlands but may flood deeper basins of more permanent wetlands and prevent their use as feeding habitat. Shorebird migrants of interior North America appear to have responded to high spatiotemporal variability in habitat by being highly vagile and able to use habitats opportunistically (Skagen and Knopf 1993, Skagen et al. 2008).

Researchers often recommend that conservation efforts maintain a diverse assemblage of wetlands within complexes to accommodate the niche requirements of the species assemblage of migrant shorebirds that move through a region (Haig et al. 1998, Skagen 2006). However, only recently have studies attempted to address this conservation challenge by focusing on the distribution patterns of multiple shorebird species at broad scales (Skagen et al. 2005, Niemuth et al. 2006, Webb et al. 2010). One of the issues that researchers face when conducting these landscape-level analyses is designating an appropriate observational scale. At fine spatial scales (i.e., the biologically relevant scale of a discrete habitat patch to the focal organism or process), migrant bird distributions are closely related to food availability (Hutto 1985); but at broad spatial scales (i.e., the biologically relevant scale of a landscape to the focal organism or process), migrant bird distributions may be more closely related to habitat availability (Buler et al. 2007). Thus, differences in the observational scale used among studies could lead to conflicting recommendations for conservation efforts. Furthermore, because the habitat-use patterns of migrant shorebirds may depend not only on the composition of the focal wetland, but also on the composition of the peripheral land-cover types (e.g., area of developed land cover) that surround the wetland (Flather and Sauer 1996, Skagen et al. 2005), an understanding of how landscapescale attributes influence shorebird distribution patterns during migration is critical for development and implementation of large-scale conservation efforts.

Shorebird conservation strategies, especially for species that migrate through the interior of North America, require the identification of broad-scale factors that influence en route habitat use (Skagen et al. 2005, 2008). Previous studies have indicated that these factors may play an important role in influencing shorebird distribution patterns (Skagen et al. 2005, Niemuth et al. 2006, Webb et al. 2010). However, the shifting distributions of wetland habitats and shorebirds on the landscape continue to make the assessment of broad-scale habitat associations challenging. In fact, Skagen et al. (2005) emphasized the need to recognize and incorporate the shifting distributions of habitats and shorebirds on the landscape into shorebird conservation programs. Currently, shorebird conservation strategies are limited without broad-scale quantitative information on how these species respond to changing landscapes (e.g., changing land-use practices and climate change) and the availability of wetlands.

We examined the relationship between migrant shorebird richness and abundance and the landscape composition of saturated and shallow-water habitats and other land-cover types in north-central Oklahoma. Specifically, our objectives were to (1) identify shorebird habitat and use successive habitat surveys to estimate the changing availability of these habitats within landscapes over time; (2) quantify the composition of semi-natural and developed land-cover types that were not defined as shorebird habitat within landscapes; and (3) examine landscape-level relationships between shorebird richness and the abundance of different shorebird groups, and the landscape composition of different shorebird habitats and nonhabitat land-cover types. Our expectations were that the richness and abundance of shorebirds during migration would be positively related to the area of shorebird habitat within landscapes regardless of the composition of other landcover types, and that relationships with shorebird habitat types would differ among shorebird groups.

\section{Methods}

Study area.-The study area comprised 10 counties of northcentral Oklahoma, which encompass a total area of $24,372 \mathrm{~km}^{2}$ and are characterized by intensively managed agricultural areas, grasslands, small forest stands, and broadly distributed urban and suburban developments (Fig. 1A). Wetlands within the study area range from more permanently flooded lacustrine and riverine wetlands to highly ephemeral palustrine wetlands and sheetwater in agricultural fields. Erratic and extreme seasonal and annual weather patterns characterize the region and cause the distribution and extent of shorebird habitat to vary widely in both space and time (Albanese et al. 2012). The average temperature and precipitation totals across the study area during the three spring study periods (March-May) were $14.4^{\circ} \mathrm{C}$ and $10.1 \mathrm{~cm}$ (long-term 


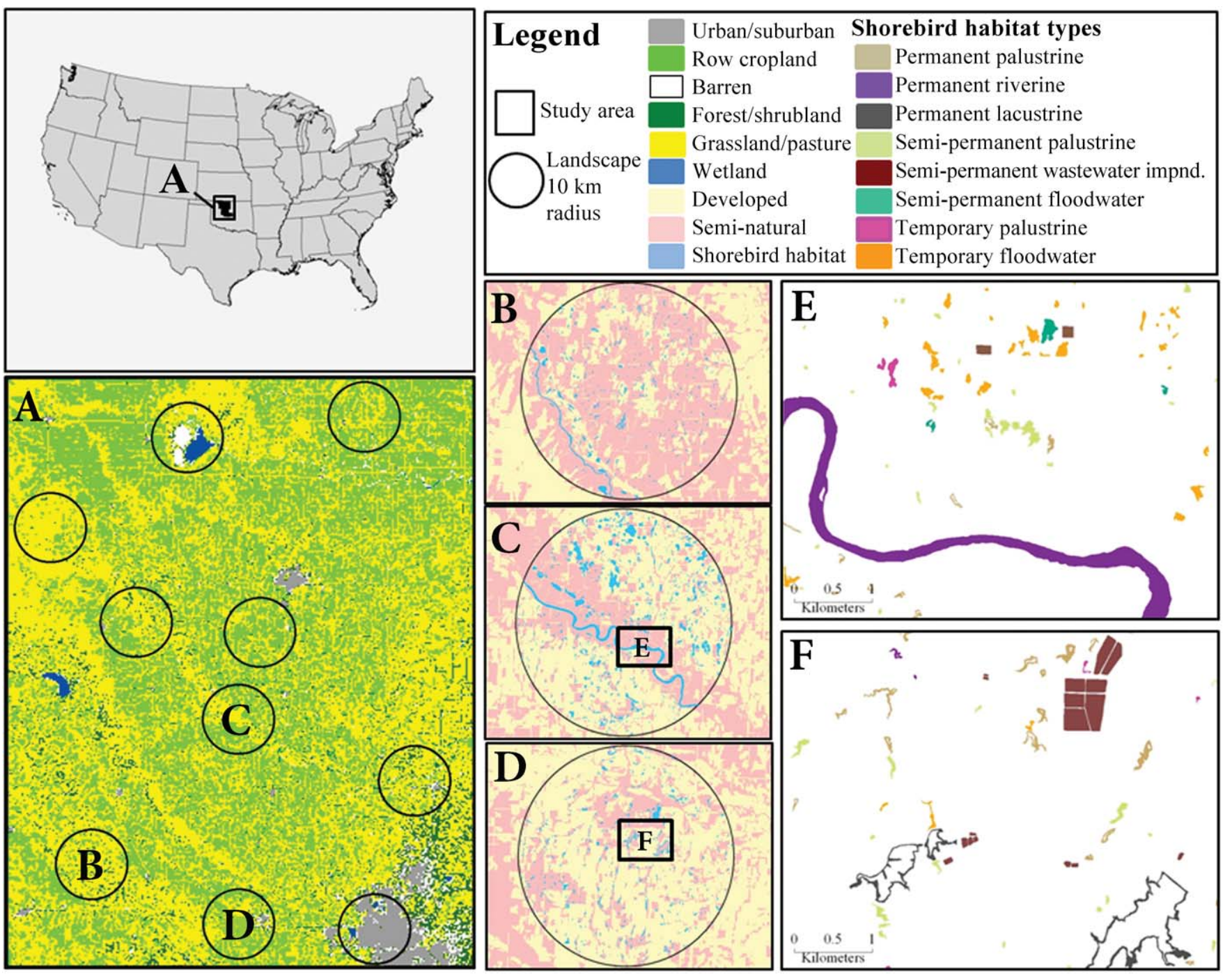

FIG. 1. Study area and landscapes in north-central Oklahoma. (A) Locations of the 10 study landscapes and distribution of initial land-cover types. (B-D) Distributions of the condensed land-cover and wetland shorebird habitat classes used in the analysis for three of the landscapes. (E, F) Examples of the distribution of wetland shorebird habitat types within landscapes.

averages: $14.4^{\circ} \mathrm{C}$ and $8.9 \mathrm{~cm}$ ), respectively, and during the two fall study periods (July-October) were $23.0^{\circ} \mathrm{C}$ and $8.8 \mathrm{~cm}$ (long-term averages: $23.4^{\circ} \mathrm{C}$ and $7.4 \mathrm{~cm}$ ), respectively (Oklahoma Climatological Survey 2011).

Experimental design.-Our research focused on migrant shorebirds in two suborders, Scolopaci and Charadrii. Within the study area, the spring migration period of shorebirds typically begins during late February and ends in early June, and the fall migration period begins in mid-July and ends in October. Accordingly, we conducted our study during five consecutive spring (March to May) and fall (mid-July to October) migration periods from 2007 to 2009. Although some shorebird species use dry upland habitat types for foraging during migration, we restricted our research to saturated and shallow-water areas and to those shorebird species that predominantly use these areas for foraging during migration.

We randomly selected 10 non-overlapping $10-\mathrm{km}$-radius areas (hereafter "landscapes") from across the study area (Fig. 1A). We chose the $10-\mathrm{km}$ radius because $>90 \%$ of known foraging flight distances of a common shorebird species in the region, the Pectoral Sandpiper (Calidris melanotos), were $<10 \mathrm{~km}$ during a migration stopover (Farmer and Parent 1997). In addition, landscapes of this size encompassed the spatial scales at which the regional migratory shorebird community had the strongest relationship with wetland habitat composition and configuration (Albanese et al. 2012), and these landscapes likely provide the spatial and temporal variability that shorebirds experience at stopover sites. We estimated that a sample size of 10 landscapes would be required to detect an effect in shorebird abundance using an a priori regression power analysis for sample size $(\alpha=0.05,1-\beta=0.90$; Lenth 2006) with variance and effect size estimates from pilot-study data.

Quantifying shorebird habitat.-We used ARCGIS, version 9.0 (ESRI, Redlands, California), to assemble 1.0-m resolution 1:12,000 digital ortho-image quarter quadrangles (DOQQs) from 2000, 2003-2006, and 2008 to quantify the area of shorebird habitat within each landscape. Because our research interests 
included only shorebird species associated with wetland habitat during migration, we restricted our definition of shorebird habitat to areas that contained saturated substrate and shallow water $(<16 \mathrm{~cm})$ within wetlands and around wetland edges in at least 1 year among these images. Within each landscape, we visually examined the entire extent of each DOQQ within the annual series at a 1:10,000 scale. When we located a discrete patch of shorebird habitat, we delineated the broadest contiguous extent of saturated substrate and shallow water that we could identify among the images as a polygon. Using long-term weather data summaries collected from 10 automated weather stations located within or near each landscape (Oklahoma Climatological Survey 2011) and visual assessments of all DOQQs, we then assigned each patch to permanent, semi-permanent, or temporary hydroperiod classes and to one of the following types: wastewater impoundment (i.e., excavated depressions used for storage, treatment, and processing of wastewater), floodwater (i.e., flooded areas that are rainwater dependent and lack a well-defined basin), riverine system, lacustrine system, or palustrine system (Cowardin et al. 1979) (Fig. 1E-F). We defined temporary, semi-permanent, and permanent classes as wetland inundation occurring only during wet years, not occurring in at least one dry year, and occurring in all years from 2000 to 2009, respectively. Although each landscape was assessed independently using available imagery and data, belowaverage precipitation and less wetland habitat characterized the 2004, 2005, and 2006 images, whereas above-average precipitation and abundant wetland habitat characterized 2000, 2003, and 2008 images (Oklahoma Climatological Survey 2011). Because of logistical limitations, we did not delineate habitat patches that never exceeded $1,000 \mathrm{~m}^{2}$ or areas within stream or river channels that did not exceed $30 \mathrm{~m}$ in width among DOQQs. To refine our habitat delineations and classifications, we then conducted field surveys of all delineated patches using 1- $\mathrm{m}^{2}$ color ortho images marked with Universal Transverse Mercator grid lines in conjunction with global positioning system receivers. We used the data collected during these field surveys to revise the shorebird habitat delineations and classifications initially made using the DOQQs.

Quantifying land cover.-We used the 2001 National Land Cover Data to quantify the area covered by different land-cover types within each landscape (Voglemann et al. 2001). Fifteen land-cover subclasses were present within the study area. Using ARCGIS, we combined subclasses that were defined by the same dominant land-cover types (Vogelmann et al. 2001) into six classes. We then further combined these six land-cover classes into two final classes based on the level of anthropogenic activity. The urban-suburban and row cropland classes were combined to form the developed class (mean hectares per landscape = 16,079 ; coefficient of variation $[\mathrm{CV}]=45.1 \%$ ), and the barren, forest-shrubland, grassland-pasture, and wetland non-shorebirdhabitat (i.e., permanent deepwater areas within wetlands) classes were combined to form the semi-natural class (mean hectares per landscape $=13,294 ; \mathrm{CV}=51.1 \%)$. Within each landscape, the shorebird habitat (mean hectares per landscape $=605, \mathrm{CV}=$ 96.2\%) delineations were then overlaid onto the developed and semi-natural land-cover classes. These three discrete land-cover classes were used in the analysis (Fig. 1B-D).

Shorebird surveys.-Existing data on known residency periods for midcontinental shorebirds during a stopover event suggest a maximum average residency period of 10.5 days (Skagen and Knopf 1994b, Farmer and Durbian 2006, Skagen et al. 2008). Accordingly, we assumed that separating our survey bouts within landscapes by $>10.5$ days would ensure independence among our survey data. Therefore, we divided each spring and fall migration period into four 23-day survey intervals and randomly selected survey dates prior to each interval. We surveyed $13-15 \%$ of the total area of shorebird habitat within each landscape once during each survey interval. We estimated that a sample size of $13 \%$ of the total shorebird habitat area within each landscape would be required to detect an effect on shorebird abundance using an a priori regression power analysis (Lenth 2006) for sample size $(\alpha=0.05,1-\beta=0.95)$ with variance and effect size estimates from pilot-study data. We randomly selected (without replacement) a unique sample of habitat in each landscape for each survey interval. Within each landscape, the proportion of the area sampled in each habitat type was equal to the proportion of the total habitat area within the landscape that each habitat type encompassed.

We conducted shorebird surveys during daylight hours from a vehicle or on foot, depending on the visibility or location of the habitat patch. After arriving at a habitat patch, we waited several minutes before initiating a survey. First, we recorded the presence or absence of shorebird habitat within the patch. We considered habitat absent if habitat patches were either completely dry or completely inundated with water $>16 \mathrm{~cm}$ in depth. If habitat was present, we surveyed the patch for shorebirds. Each habitat patch $\leq 1$ ha was surveyed for a minimum of 5 min during a visit, and equal time was added for each additional hectare of habitat. We observed shorebirds with a $10 \times 60$ spotting scope or $8 \times 40$ binoculars. We identified and counted all shorebirds observed in a habitat patch. We classified shorebird species as either migrants or residents and then further classified migrant species as short-, intermediate-, or long-distance migrants (Skagen and Knopf 1993; Table 1).

Statistical analysis.-All analyses were performed using R, version 2.12.1 ( $\mathrm{R}$ Development Core Team 2010). All data were tested for normality and homogeneity of variance and transformed when necessary. Logarithmic transformations were used successfully to achieve homogeneity of variance and normal distributions for species abundance, richness, and habitat and landcover data.

To identify which models best explained observed patterns in shorebird abundance and richness among analyses, we used an information-theoretic framework to compare alternative models (Burnham and Anderson 2002). We used the second-order variant of Akaike's information criterion ( $\mathrm{AIC}_{\mathrm{c}}$ ) to compare the relative ability of alternative models to explain observed patterns. We considered all models with $\triangle \mathrm{AIC}_{c}<6$ to have support, but selected only models for which the $\mathrm{AIC}_{\mathrm{c}}$ value was less than the $\mathrm{AIC}_{\mathrm{c}}$ values of all the simpler models within which they were nested (Richards 2008). We used Akaike weights to calculate composite model parameter estimates and summed Akaike weights for each parameter in the "best model" set (Burnham and Anderson 2002).

Land-cover analysis.-We used multiple linear regression to model separately the total abundance and species richness of migratory shorebirds as a function of the area of shorebird habitat, developed land cover, and semi-natural land cover within each landscape. For the variable shorebird habitat area, we used field 
TABLE 1. List of shorebird species encountered within wetland habitats in north-central Oklahoma, 2007-2009. Shorebirds are listed by class assignments used for analysis. Class assignments were based on current breeding status within the study area (Reinking 2004) and migration distance (Skagen and Knopf 1993). Mean number of individuals observed and standard error (SE) for each shorebird class and species richness are per landscape for each survey interval.

\begin{tabular}{lc}
\hline Species & Mean \pm SE \\
\hline Resident & $37.5 \pm 4.3$ \\
Snowy Plover (Charadrius nivosus) & \\
Killdeer (Charadrius vociferus) & \\
Spotted Sandpiper (Actitis macularius) & \\
Short-distance migrants & \\
American Avocet (Recurvirostra americana) & \\
Black-necked Stilt (Himantopus mexicanus) & \\
Willet (Tringa semipalmata) & \\
Long-billed Curlew (Numenius americanus) & \\
Marbled Godwit (Limosa fedoa) & \\
Wilson's Snipe (Gallinago delicata) & \\
Intermediate-distance migrants & \\
Black-bellied Plover (Pluvialis squatarola) & \\
Semipalmated Plover (Charadrius semipalmatus) & \\
Lesser Yellowlegs (Tringa flavipes) & \\
Greater Yellowlegs (Tringa melanoleuca) & \\
Solitary Sandpiper (Tringa solitaria) & \\
Whimbrel (Numenius phaeopus) & \\
Long-billed Dowitcher (Limnodromus scolopaceus) & \\
Wilson's Phalarope (Phalaropus tricolor) & \\
Ruddy Turnstone (Arenaria interpres) & \\
Red Knot (Calidris canutus) & \\
Sanderling (Calidris alba) & \\
Dunlin (Calidris alpina) & \\
Semipalmated Sandpiper (Calidris pusilla) & \\
Western Sandpiper (Calidris mauri) & \\
Least Sandpiper (Calidris minutilla) & \\
Red-necked Phalarope (Phalaropus lobatus) & \\
Long-distance migrants & \\
American Golden-Plover (Pluvialis dominica) & \\
Hudsonian Godwit (Limosa haemastica) & \\
White-rumped Sandpiper (Calidris fuscicollis) & \\
Pectoral Sandpiper (Calidris melanotos) & \\
Baird's Sandpiper (Calidris bairdii) & \\
Buff-breasted Sandpiper (Tryngites subruficollis) \\
Stilt Sandpiper (Calidris himantopus) & \\
Species richness & \\
\hline Species rarely breedin most of study area & \\
\hline
\end{tabular}

${ }^{a}$ Species rarely breed in most of study area.

data to calculate the proportion of each habitat type with habitat present during each survey interval in a landscape. We multiplied these proportions by the total area of each habitat type within each landscape. We summed these values to estimate the total habitat area present within each landscape during each interval. For the analysis, we used the mean of these estimates across all survey intervals in each landscape. For each dependent variable, the candidate model set included area of shorebird habitat, developed land cover, semi-natural land cover, additive combinations of shorebird habitat and each land-cover type, and a null model $(R=6)$.

Shorebird habitat analysis.-We used linear time-series regression (Ives and Zhu 2006) to model separately the abundance of shorebirds in each response group and shorebird species richness as a function of the area of different shorebird habitat types among survey intervals within landscapes. For each landscape, we used the methods described above to estimate the area of habitat present. However, for this analysis, we separately estimated the area of each habitat type during each interval and calculated the abundance of shorebirds in each response group and total species richness during each corresponding interval. Candidate model sets included a null model and all additive combinations of habitat types $(R=256)$. Initially we included year and season variables in each candidate set of variables, but because these variables did not contribute to these models, we excluded them from the analysis.

To test for spatiotemporal autocorrelation among these data, we first fitted each global model with no correlation structure. We examined plots of normalized residuals versus time for each landscape time-series and the correlation coefficients between residuals among landscape time-series (Zuur et al. 2009). Correlation coefficients between residuals among landscape time-series did not indicate spatial correlation among landscapes; however, temporal correlation within landscape time-series was apparent. We therefore fitted global models with ordered and moving average autoregressive structures, AR (1) and ARMA, respectively (Ives and Zhu 2006, Zuur et al. 2009), and compared models using AIC . The models with the AR (1) structure consistently eliminated evidence of temporal autocorrelation among residuals and had the lowest $\mathrm{AIC}_{\mathrm{c}}$ value among models. Consequently, we used the AR (1) structure and maximum likelihood estimation to estimate model parameters in the analysis. For each time-series, we used subsequent observed values to estimate habitat area values for $t(0)$. The fit of all global models to the data was assessed using residual deviance goodness-of-fit tests.

\section{Results}

We delineated and classified 11,733 ha of shorebird habitat among landscapes. During the entire study, habitat was present at the time of a survey in $58 \%$ of the habitat patches that were surveyed. Among landscapes, the permanent riverine and temporary floodwater habitat types provided the highest mean area of shorebird habitat, and permanent lacustrine habitat had the highest variance among landscapes (Table 2).

We observed 44,266 shorebirds that included 32 species (Table 1). Of these, 6,644 individuals were resident breeders in the study area. Among migratory species, intermediate- and long-distance migrants were the most abundant $(n=23,199$ and 12,253, respectively).

Land-cover analysis.-Mean shorebird habitat area was included in the most parsimonious models to predict total shorebird abundance $\left(w_{i}=0.63\right)$ and shorebird species richness $\left(w_{i}=0.46\right)$ based on land-cover types within landscapes. Across all candidate models considered in each analysis, the summed Akaike weights for this variable $(w+(j)=0.99$ and 0.97 for abundance and richness, respectively) indicated with high certainty the importance of the amount of shorebird habitat regardless of the amount of either developed or semi-natural land cover in the landscape. Migratory shorebird abundance and species richness were both positively correlated with the total area of shorebird habitat within landscapes (Fig. 2). 
TABLE 2. Summary statistics of wetland habitat types present during the study of 10 landscapes in north-central Oklahoma, 2007-2009. Statistics include the total sample of habitat patches surveyed, the mean $( \pm$ SE) of the estimates of the habitat area (ha) present, and the mean proportion $( \pm$ SD) of the number of surveyed habitat patches with habitat present during a survey. The summed Akaike weights are included only for wetland habitat types that occurred in each "best model" set $\left(\Delta \mathrm{AIC}_{\mathrm{c}}<6\right)$ from the time-series regression analyses of shorebird species richness, the abundance of resident $(\mathrm{R})$, short-distance $(\mathrm{S})$, intermediate-distance (I), and long-distance (L) migrant shorebirds as a function of the amount of each wetland habitat type within a landscape.

\begin{tabular}{|c|c|c|c|c|c|c|c|c|}
\hline \multirow[b]{3}{*}{ Habitat type } & \multirow[b]{3}{*}{$n$} & \multirow[b]{3}{*}{$\begin{array}{c}\text { Area } \\
(\text { mean } \pm \mathrm{SE})\end{array}$} & \multirow[b]{3}{*}{$\begin{array}{l}\text { Proportion } \\
(\text { mean } \pm \mathrm{SD})\end{array}$} & \multicolumn{5}{|c|}{ Relative importance of habitat variables $(w+(j))$} \\
\hline & & & & \multirow[b]{2}{*}{ Species richness } & \multicolumn{4}{|c|}{ Abundance } \\
\hline & & & & & $\mathrm{R}$ & S & I & L \\
\hline Permanent lacustrine & 582 & $56.6 \pm 34.9$ & $0.47 \pm 0.5$ & & 0.25 & 0.75 & & \\
\hline Permanent riverine & 1,287 & $216.0 \pm 24.1$ & $0.76 \pm 0.4$ & 0.56 & & & 0.88 & \\
\hline Permanent palustrine & 1,783 & $49.7 \pm 2.4$ & $0.64 \pm 0.5$ & & 0.08 & & & \\
\hline Semi-permanent floodwater & 446 & $34.0 \pm 3.6$ & $0.79 \pm 0.4$ & 0.90 & 0.71 & & 0.50 & 0.50 \\
\hline Semi-permanent palustrine & 2,631 & $62.3 \pm 3.1$ & $0.76 \pm 0.4$ & & 0.29 & & & \\
\hline $\begin{array}{l}\text { Semi-permanent wastewater } \\
\text { impoundment }\end{array}$ & 393 & $3.7 \pm 0.05$ & $0.26 \pm 0.4$ & & & & & \\
\hline Temporary floodwater & 5,958 & $161.3 \pm 14.3$ & $0.69 \pm 0.5$ & 0.97 & & & 0.82 & 0.94 \\
\hline Temporary palustrine & 623 & $11.1 \pm 1.0$ & $0.46 \pm 0.5$ & & & & 0.25 & \\
\hline
\end{tabular}
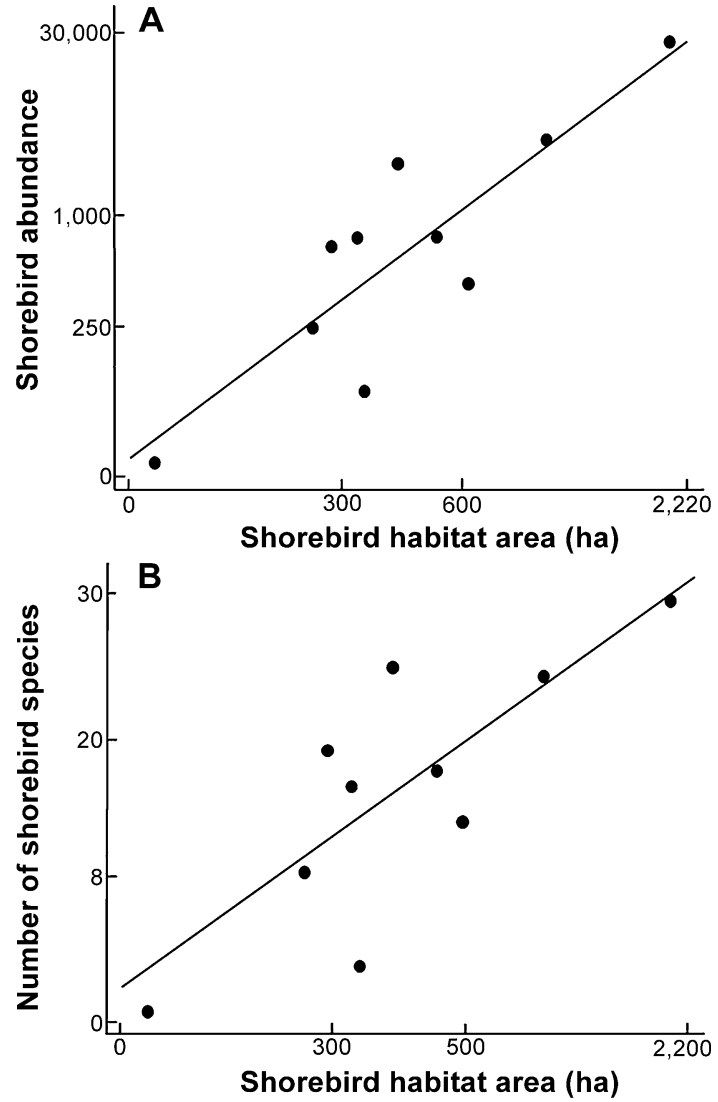

FIG. 2. Relationship between abundance and species richness of migratory shorebirds and the mean area of wetland shorebird habitat within a landscape. (A) Relationship between the number of migratory shorebirds and the mean area of wetland shorebird habitat within landscapes: $\log (y)=$ $-3.803+2.459 \times \log (x) ; r^{2}=0.73, n=10$. (B) Relationship between the number of migratory shorebird species and the mean area of wetland shorebird habitat within landscapes: $\log (y)=0.5297+0.6038 \times \log (x) ; r^{2}=$ $0.59, n=10$. Note that graph axis values are untransformed.
Shorebird habitat analysis.-Permanent lacustrine habitat, semi-permanent palustrine habitat, and semi-permanent floodwater habitat were included in the most parsimonious models to predict the abundance of resident shorebirds based on the area of shorebird habitat types within landscapes (Table 3). For shortdistance migrant abundance, the most parsimonious model included the variable permanent lacustrine habitat area (Table 3). Across all models considered in the analysis of intermediatedistance migrant abundance, the amount of permanent riverine and temporary floodwater habitats had the highest importance values (Table 2). The most parsimonious models to predict the abundance of long-distance migrants included the amount of semi-permanent and temporary floodwater habitats (Table 3), and the summed Akaike weights indicate with high certainty the importance of these variables (Table 2).

The most parsimonious models to predict species richness included the amount of permanent riverine habitat, semipermanent floodwater habitat, and temporary floodwater habitats within landscapes (Table 3), and the summed Akaike weights indicate with high certainty the importance of the floodwater habitat variables (Table 2). Model-averaged coefficients from these analyses all indicated that relationships between response groups and habitat types were positive.

\section{Discussion}

In the southern Great Plains, the abundance and species richness of migratory shorebirds increased with the area of shorebird habitat within 10-km-radius landscapes. Our results thus support the theoretical model of habitat selection by migratory birds in which migrants initially select en route stopover areas on the basis of broad-scale characteristics and proceed to finer-scale habitat features within stopovers (Hutto 1985, Moore and Aborn 2000, Deppe and Rotenberry 2008). En route migratory birds may use broad-scale habitat composition as a coarse-level cue to select a landing site at the end of a migratory flight, and this choice, as a consequence, may determine the distribution of migrants within 
TABLE 3. Minimum $\triangle \mathrm{AIC}_{\mathrm{c}}$ (i.e., $<6^{\text {a) }}$ and Akaike weights $\left(w_{i}\right)$ of best-supported time-series regression models of shorebird abundance in each distance group and total shorebird richness dependent on total area of wetland shorebird habitat types in 10 landscapes within north-central Oklahoma, 2007-2009.

\begin{tabular}{llrr}
\hline Response group & Selected alternative models & $\Delta \mathrm{AIC}_{\mathrm{c}}$ & $w_{i}$ \\
\hline Resident & Semi-permanent floodwater & 0 & 0.67 \\
& Permanent lacustrine, semi-permanent palustrine & 2.07 & 0.24 \\
& Permanent palustrine, semi-permanent palustrine & 5.59 & 0.04 \\
Short-distance & Permanent lacustrine & 0 & 0.39 \\
Intermediate-distance & Permanent riverine, semi-permanent floodwater, temporary floodwater & 0 & 0.33 \\
& Permanent riverine, temporary floodwater & 0.29 & 0.29 \\
& Permanent riverine, temporary palustrine & 3.00 & 0.07 \\
& Semi-permanent floodwater, temporary floodwater & 4.09 & 0.04 \\
& Temporary floodwater & 4.45 & 0.04 \\
& Permanent riverine, semi-permanent floodwater & 5.29 & 0.02 \\
& & 0 & 0.33 \\
Long-distance & Semi-permanent floodwater, temporary floodwater & 0.27 & 0.32 \\
& Temporary floodwater & 3.80 & 0.05 \\
Sichness & Semi-permanent floodwater & 0 & 0.42 \\
& Permanent riverine, semi-permanent floodwater, temporary floodwater & 1.35 & 0.21 \\
& Semi-permanent floodwater, temporary floodwater & 5.16 & 0.03 \\
\hline
\end{tabular}

a Alternative candidate models were selected for the "best model" sets only when the $\mathrm{AIC}_{\mathrm{c}}$ value for a model was less than the AIC $\mathrm{c}_{\mathrm{c}}$ values of all the simpler models within which they were nested (Richards 2008).

a region (Buler et al. 2007). By selecting landscapes with greater amounts of stopover habitat, migrating shorebirds are more likely to minimize energetic costs associated with locating resources because more habitat available within shorter distances results in improved energetic intake (Farmer and Parent 1997). Positive relationships between migratory shorebird richness and the area of wetland habitat within landscapes is not surprising, considering that species richness generally increases with habitat area because more habitats are available to accommodate more interspecific niche requirements (MacArthur and Wilson 1967).

We found no evidence that the area of developed or seminatural land cover affected the abundance and richness of migratory shorebirds among landscapes within our study area. Direct comparisons with other studies are limited because landscape-level studies mainly examine the influence of landscapecontext variables (e.g., habitat composition or configuration measured from a focal habitat patch using buffers, linear distance measured between patches, or connectivity metrics) on the habitat-use patterns of migrating birds or treat nonhabitat within landscapes as a neutral matrix (Thornton et al. 2011). Additionally, the results of studies that examined the influence of surrounding land cover on shorebird use of stopover habitats have been equivocal (Skagen et al. 2005, Webb et al. 2010). While factors related to the types of land cover surrounding a wetland may influence the use of a wetland, the amount of wetland habitat at broad spatial scales may also be an important factor influencing shorebird abundance and richness. This may be especially true for interior migrating shorebirds because they encounter substantial spatiotemporal variation in the distribution of wetland resources (Skagen and Knopf 1993, Skagen et al. 2008, Albanese et al. 2012).
Patterns of shorebird abundance across habitat types differed greatly in relation to the migration strategy of the species and reflected primarily the relative permanency of the wetlands. However, our estimates of shorebird abundance across different habitats may have been somewhat biased because we did not account for potential differences in detection probability, but we suspect that any bias is minimal. In our study area, only $13.6 \%$ of the area classified as shorebird habitat had characteristics related to vegetation structure ( $>5 \%$ vegetation cover, and vegetation height $>0.5 \mathrm{~m}$; Albanese 2011) that have been noted to depress the detection of migrant shorebirds in our study region (Farmer and Durbian 2006). The potential for underestimation of shorebird abundance would have been greatest for floodwater areas, which had the tallest vegetation. However, any bias in our data would have been minimal because the vast majority of the areas surveyed were sparsely vegetated and most of the shorebird species in our region avoid areas with dense vegetation (Davis and Smith 1998).

The amounts of permanent and semi-permanent habitat types were important predictors of resident shorebird abundance. To meet the requirements associated with the breeding portion of their life cycle, shorebird species breeding in this region likely require the longer hydroperiods of more permanent wetland types (Conway et al. 2005a, b). However, this constraint may not apply to migratory shorebirds that forage and use habitat opportunistically during migration (Skagen and Knopf 1994a, Skagen and Oman 1996, Davis and Smith 2001). Wetland resources required by some migrating shorebirds need be accessible for only a short period (i.e., hours to days), and decisions by a bird to continue migration or remain at a stopover site may be influenced by the bird's present body condition and the quality and availability of wetland habitats along the entire route (Colwell 2010). 
By contrast, the availability of transitory floodwater areas was an important predictor of intermediate and long-distance migrant abundance. Broad-scale expanses of high-density floodwater occurred after heavy precipitation, and the resulting habitats within the flooded wetland clusters provided highly connected stopover sites at the spatial scales that best explained migrant shorebird distribution patterns (Albanese et al. 2012). When abundant, floodwater areas were generally characterized by substantial mud flats and shallow water within the range of shorebird foraging depths (i.e., $<16 \mathrm{~cm}$; Davis and Smith 1998). When replete, these transient habitats expose previously inaccessible and possibly abundant prey resources to foraging shorebirds. Migrating shorebirds can process food and assimilate energy at exceedingly high rates (Kvist and Lindström 2003), and fat reserves increase with impending migration distance (Piersma and Gill 1998). The broad- and finescale characteristics of abundant floodwater habitat may best provide efficient and gainful access to the food resources necessary for successful completion of migration. By contrast, the importance of lacustrine areas to short-distance migrants may reflect the less restrictive time constraints and physiological demands of a shorter migration route and more southerly breeding distribution. These species may better afford the additional time and energy that may be necessary to locate resources at broad and fine spatial scales in more predictable and stable habitats.

Our results indicate that riverine and more transitory floodwater areas were important predictors of species richness. During migration, the use of wetlands varies among shorebird species as vegetation cover, water depth, and ratio of saturated substrate and shallow water change (Skagen and Knopf 1994a; Davis and Smith 1998, 2001), and increased variation in these factors is positively related with the occurrence and abundance of migrating shorebirds within wetlands (Niemuth et al. 2006, Webb et al. 2010). Within our study area, riverine and floodwater wetlands typically encompassed a broad range of microhabitats, whereas the shorelines of lacustrine and many palustrine wetlands were generally of similar water depth, vegetation cover, and ratio of saturated substrate to water.

Temporary floodwater areas in our study area comprised many relatively small and discrete patches that individually hosted relatively low numbers of shorebirds and species, but collectively provided habitat for high numbers of individuals and species. Several studies have highlighted the importance of ephemeral wetlands to migrant shorebirds (Davis and Smith 1998, Niemuth et al. 2006, Skagen et al. 2008). Most notably, Skagen et al. (2008) demonstrated that ephemeral wetlands in the northern Great Plains provide important stopover resources, but that they have been overlooked because of their smaller size, lack of large and discrete shorebird congregations, and their shifting and unpredictable nature in time and space. Our results further emphasize the importance of these wetlands to shorebirds because they indicate that beyond providing vital stopover resources at fine scales, landscapes with abundant ephemeral wetlands provide habitat for numerous and diverse migratory shorebird assemblages.

These findings emphasize the need for shorebird conservation efforts to maintain broad-scale wetland clusters that include abundant riverine wetlands and ephemeral floodwater. Within our study area, extensive tracts of riverine wetlands remain relatively unaltered by anthropogenic activities and are characterized by braided channels with mobile, sandy substrates and variable water-depth profiles. Concurrently, seasonal heavy precipitation events create localized expanses of abundant floodwater that are spatiotemporally dynamic and include an extensive array of water, exposed substrate, and vegetation characteristics. However, forecasts of a warmer and drier climate (Intergovernmental Panel on Climate Change 2007) and pervasive land-use change within the region may alter the contemporary processes that govern these wetlands. Furthermore, a lack of comprehensive legal protection for ephemeral wetlands (Haukos and Smith 2003) will likely lead to further wetland loss within the region. Shorebird conservation efforts for the southern Great Plains would benefit greatly from an assessment of how vulnerable different wetlands may be to predicted changes in climate and land-use patterns.

\section{ACKNOWLEDGMENTS}

S. D. Fuhlendorf, B. Luttbeg, S. K. Skagen, P. D. Vickery, N. Warnock, and an anonymous reviewer provided valuable comments that greatly improved the manuscript. This study was funded by an Oklahoma Department of Wildlife Conservation State Wildlife Grant that was administered through the Oklahoma Cooperative Fish and Wildlife Research Unit. We gratefully acknowledge additional support provided by the Department of Natural Resource Ecology and Management at Oklahoma State University, Oklahoma Cooperative Fish and Wildlife Research Unit, Great Plains Landscape Conservation Cooperative, U.S. Geological Survey, and U.S. Fish and Wildlife Service. We also thank the thousands of private landowners for access to their properties. We thank field assistants R. Torres-Cervantes, L. W. Elmore, and A. Nealis, and we especially thank S. D. Albanese, S. K. Albanese, K. Andersson, B. W. Compton, and S. Sullivan, whose tireless efforts made this project possible.

\section{Literature Cited}

Albanese, E. 2011. A multi-scale examination of stopover habitat use by migrant shorebirds. Ph.D. dissertation, Oklahoma State University, Stillwater.

Albanese, G., C. A. Davis, And B. W. Compton. 2012. Spatiotemporal scaling of North American continental interior wetlands: Implications for shorebird conservation. Landscape Ecology 27:1465-1479.

Baker, A. J., P. M. González, T. Piersma, L. J. Niles, I. L. S. do Nascimento, P. W. Atkinson, N. A. Clark, C. D. T. Minton, M. K. PeCK, And G. Aarts. 2004. Rapid population decline in Red Knots: Fitness consequences of decreased refuelling rates and late arrival in Delaware Bay. Proceedings of the Royal Society of London, Series B 271:875-882.

Brown, S., C. Hickey, B. Harrington, And R. Gill, Eds. 2001. United States Shorebird Conservation Plan, 2nd ed. Manomet Center for Conservation Sciences, Manomet, Massachusetts. [Online.] Available at www.fws.gov/shorebirdplan/USShorebird/ downloads/USShorebirdPlan2Ed.pdf.

Buler, J. J., F. R. Moore, and S. Woltmann. 2007. A multiscale examination of stopover habitat use by birds. Ecology 88:1789-1802. 
Burnham, K. P., And D. R. Anderson. 2002. Model Selection and Multimodel Inference: A Practical Information-Theoretic Approach, 2nd ed. Springer-Verlag, New York.

Colwell, M. A. 2010. Shorebird Ecology, Conservation and Management. University of California Press, Berkeley.

Conway, W. C., L. M. Smith, And J. D. Ray. 2005a. Shorebird breeding biology in wetlands of the Playa Lakes, Texas, USA. Waterbirds 28:129-138.

Conway, W. C., L. M. Smith, AND J. D. Ray. 2005b. Shorebird habitat use and nest site selection in the Playa Lakes Region. Journal of Wildlife Management 69:174-184.

Cowardin, L. M., V. Carter, F. C. Golet, and E. T. LaRoe. 1979. Classification of Wetlands and Deepwater Habitats of the United States. U.S. Department of the Interior, Fish and Wildlife Service, Washington, D.C.

Dahl, T. E., AND G. J. Allord. 1996. History of wetlands in the conterminous United States. Pages 19-26 in National Summary on Wetland Resources (J. D. Fretwell, J. S. Williams, and P. J. Redman, Eds.). U.S. Geological Survey, Springfield, Virginia.

Davis, C. A., AND L. M. SMith. 1998. Ecology and management of migrant shorebirds in the Playa Lakes region of Texas. Wildlife Monographs 140:1-45.

DAvis, C. A., AND L. M. SMith. 2001. Foraging strategies and niche dynamics of coexisting shorebirds at stopover sites in the southern Great Plains. Auk 118:484-495.

Deppe, J. L., And J. T. Rotenberry. 2008. Scale-dependent habitat use by fall migratory birds: Vegetation structure, floristics, and geography. Ecological Monographs 78:461-487.

FARMer, A. H., AND F. Durbian. 2006. Estimating shorebird numbers at migration stopover sites. Condor 108:792-807.

Farmer, A. H., AND A. H. PARENT. 1997. Effects of the broad scale on shorebird movements at spring migration stopovers. Condor 99:698-707.

Flather, C. H., ANd J. R. Sauer. 1996. Using landscape ecology to test hypotheses about large-scale abundance patterns in migratory birds. Ecology 77:28-35.

Haig, S. M., D. W. Mehlman, and L. W. Oring. 1998. Avian movements and wetland connectivity in landscape conservation. Conservation Biology 12:749-758.

Haukos, D. A., and L. M. Smith. 2003. Past and future impacts of wetland regulations on playa ecology in the southern Great Plains. Wetlands 23:577-589.

Hutto, R. L. 1985. Habitat selection by nonbreeding, migratory land birds. Pages 455-476 in Habitat Selection in Birds (M. L. Cody, Ed.). Academic Press, Orlando, Florida.

Intergovernmental Panel on Climate Change. 2007. Climate Change 2007: The Physical Science Basis. Cambridge University Press, Cambridge, United Kingdom.

Ives, A. R., AND J. ZHU. 2006. Statistics for correlated data: Phylogenies, space, and time. Ecological Applications 16:20-32.

JehL, J. R., JR., AND W. Lin. 2001. Population status of shorebirds nesting at Churchill, Manitoba. Canadian Field-Naturalist 115:487-494.

Kvist, A., AND Å. LindSTRÖM. 2003. Gluttony in migratory waders-Unprecedented energy assimilation rates in vertebrates. Oikos 103:397-402.

LENTH, R. V. 2006. Java applets for power and sample size. [Online.] Available at www.stat.uiowa.edu/ rlenth/Power.
MacArthur, R. H., And E. O. Wilson. 1967. The Theory of Island Biogeography. Princeton University Press, Princeton, New Jersey.

Moore, F. R., AND D. A. ABorn. 2000. Mechanisms of en route habitat selection: How do migrants make habitat decisions during stopover? Pages 34-42 in Stopover Ecology of Nearctic-Neotropical Landbird Migrants: Habitat Relations and Conservation Implications (F. R. Moore, Ed.). Studies in Avian Biology, no. 20.

MORRISON, R. I. G. 2006. Body transformations, condition, and survival in Red Knots Calidris canutus travelling to breed at Alert, Ellesmere Island, Canada. Ardea 94:607-618.

Morrison, R. I. G., R. E. Gill, Jr., B. A. Harrington, S. Skagen, G. W. Page, C. L. Gratto-Trevor, and S. M. Haig. 2001. Estimates of shorebird populations in North America. Occasional Paper No. 104. Canadian Wildlife Service, Ottawa, Ontario.

Morrison, R. I. G., R. K. Ross, AND L. J. Niles. 2004. Declines in wintering populations of Red Knots in southern South America. Condor 106:60-70.

Niemuth, N. D., M. E. Estey, R. E. Reynolds, C. R. Loesch, And W. A. MeEks. 2006. Use of wetlands by spring-migrant shorebirds in agricultural landscapes of North Dakota's Drift Prairie. Wetlands 26:30-39.

OKlahoma Climatological Survey. 2011. Mesonet [web application]. University of Oklahoma, Norman, Oklahoma. [Online.] Available at climate.mesonet.org/.

Piersma, T. 2007. Using the power of comparison to explain habitat use and migration strategies of shorebirds worldwide. Journal of Ornithology 148:45-59.

Piersma, T., AND R. E. GILl, JR. 1998. Guts don't fly: Small digestive organs in obese Bar-tailed Godwits. Auk 115:196-203.

R Development Core Team. 2010. R: A Language and Environment for Statistical Computing. R Foundation for Statistical Computing, Vienna.

Reinking, D. L., ED. 2004. Oklahoma Breeding Bird Atlas. University of Oklahoma Press, Norman.

RiChARDS, S. A. 2008. Dealing with overdispersed count data in applied ecology. Journal of Applied Ecology 45:218-227.

Skagen, S. K. 2006. Migration stopovers and the conservation of Arctic-breeding calidridine sandpipers. Auk 123:313-322.

SKagen, S. K., S. BROWN, AND R. Johnson. 2005. Implications of different shorebird migration strategies for habitat conservation. Pages 680-683 in Bird Conservation Implementation and Integration in the Americas: Proceedings of the Third International Partners in Flight Conference, vol. 2 (C. J. Ralph and T. D. Rich, Eds.). U.S. Department of Agriculture, Forest Service, General Technical Report PSW-GTR-191.

Skagen, S. K., D. A. Granfors, and C. P. Melcher. 2008. On determining the significance of ephemeral continental wetlands to North American migratory shorebirds. Auk 125:20-29.

SKAGEN, S. K., AND F. L. KNOPF. 1993. Toward conservation of midcontinental shorebird migrations. Conservation Biology 7:533-541.

SKagen, S. K., AND F. L. KNOPF. 1994a. Migrating shorebirds and habitat dynamics at a prairie wetland complex. Wilson Bulletin 106:91-105.

SKAGEN, S. K., AND F. L. KNOPF. 1994b. Residency patterns of migrating sandpipers at a midcontinental stopover. Condor 96:949-958.

SKagen, S. K., And H. D. OMAn. 1996. Dietary flexibility of shorebirds in the Western Hemisphere. Canadian Field-Naturalist 110:419-444. 
Stroud, D. 2003. Are waders worldwide in decline? Reviewing the evidence. A workshop summary. Wader Study Group Bulletin 101-102:8-12.

Thomas, G. H., R. B. LANCTOT, And T. SzÉKely. 2006. Can intrinsic factors explain population declines in North American breeding shorebirds? Animal Conservation 9:252-258.

Thornton, D. H., L. C. Branch, And M. E. Sunquist. 2011. The influence of landscape, patch, and within-patch factors on species presence and abundance: A review of focal patch studies. Landscape Ecology 26:7-18.

Tilman, D., J. Fargione, B. Wolff, C. D’Antonio, A. Dobson, R. Howarth, D. Schindler, W. H. Schlesinger, D. Simberloff, and D. Swackhamer. 2001. Forecasting agriculturally driven global environmental change. Science 292:281-284.

Vogelmann, J. E., S. M. Howard, L. Yang, C. R. Larson, B. K. Wylie, AND J. N. Van Driel. 2001. National Land Cover
Database 2001. U.S. Geological Survey, EROS Data Center, MRLC Project, Sioux Falls, South Dakota. [Online.] Available at www. mrlc.gov/mrlc2k_nlcd.asp.

WARNOCK, N. 2010. Stopping vs. staging: The difference between a hop and a jump. Journal of Avian Biology 41:621-626.

Webb, E. B., L. M. Smith, M. P. Vrtiska, and T. G. Lagrange. 2010. Effects of local and landscape variables on wetland bird habitat use during migration through the Rainwater Basin. Journal of Wildlife Management 74:109-119.

Wetlands International. 2002. Waterbird Population Estimates, 3rd ed. Wetlands International Global Series No. 12. Wetlands International, Wageningen, The Netherlands.

Zuur, A. F., E. N. Ieno, N. J. Walker, A. A. Saveliev, And G. M. Smith. 2009. Mixed Effects Models and Extensions in Ecology with R. Springer, New York.

Associate Editor: C. M. Handel 